\title{
THE INFLUENCE OF WORK MOTIVATION AND SELF MANAGEMENT PRACTICES ON EMPLOYEE JOB SATISFACTION (CASE STUDY OF PT. BIO FARMA IN BANDUNG)
}

\author{
Didi Tarmidi', Aditya Muhammad Yusup ${ }^{2}$ \\ Faculty of Economy and Business, University of Widyatama, Bandung-Indonesia \\ didi.tarmidi@widyatama.ac.id ${ }^{l}$, aditya.muhamad@widyatama.ac.id ${ }^{\underline{2}}$
}

\begin{abstract}
This research aims to determine how the description of work motivation, self-management practices, and employee job satisfaction, as well as to determine how the influence of work motivation and self-management practices on employee job satisfaction PT. Bio Farma. The factors tested in the study were work motivation and self-management practices as independent variables, while job satisfaction was dependent variables. The research methods used in this research are descriptive and verification methods. The population in this study were employees at PT. Bio Farma. The sampling technique used in this study was Purposive Sampling and the size of the sample in this study was calculated with the formula Slovin, so the total number was 200 respondents. The analytical methods used in this study are some linear regression analyses using SPSS25 for Windows. The results of this study show that work motivation and self-management practices affect employee job satisfaction at PT. Bio Farma. The effect of work motivation and self-management practices on employee job satisfaction was $59.3 \%$.
\end{abstract}

Keywords: Work motivation; Self Management Practices; Job Satisfaction

\section{Introduction}

Quality human resources are the main points needed in the era of globalization. Every organization always hopes that resources can work normally and correctly to achieve the company's goals as expected. The core element of an organization is human resources. What its purpose is, the organization's need for humans in various visions and the execution of tasks is adjusted and regulated by humans. Therefore, humans are the part that determines the process of achieving the goals of an organization. (Ekhsan, 2019:2)

Employees who have a high level of job satisfaction will tend to be more committed and contribute and have a high dedication to the company and eventually have the willingness to work harder and more productively. Conversely, employees with low levels of job satisfaction are likely to commit a turnover, as well as decreased work motivation (Robbins, 2017).

One of the factors that affect job satisfaction in work motivation. Work motivation is a process by which they need encourages a person to carry out a series of activities that lead to the achievement of a particular goal. The goals that are successfully achieved will satisfy or meet these needs (Ira Rahmadita, 2016). The more precise the effort to provide motivation, the higher 
the productivity of labor, as a result of benefiting both the company and employees (Ayoe Permatasary and Rostiana D. Nurdjajadi, 2018: 182).

In addition to work motivation, another factor that affects job satisfaction is selfmanagement practices. Self-management practices have been important elements of new organizations since the 1990s. Self-management practices are central to the new economic paradigm for the era of information and are an important determinant for the success of an organization (Castaneda \& Aldag, 2016). Self-management expertise is crucial to employee career success in the organization and in adjusting organizational commitment and organizational culture in the future (King, 2015). This study aimed to test the effect of work motivation and selfmanagement practices on job satisfaction.

\section{Frame of Mind}

A framework of thought is a conceptual model of how theory is combined with a variety of factors that have been identified as important issues. A good frame of mind would theoretically explain the interrelationships between the variables studied. So it is theoretically necessary to explain the relationship between independent and dependent variables. Effect of Work Motivation and Self Management Practices on Employee Job Satisfaction.

Motivation means encouraging, motiv moon or things that cause encouragement or circumstances that cause encouragement. It can also be said that motivation is a factor that drives people to act in a certain way. According to T. Hani Handoko (2018: 252), motivation is a state in one's person that encourages the individual's desire to perform certain activities to achieve goals. According to David Mc. Clelland with the theory of achievement motivation in Edy Sutrisno (2016: 128) describes three basic components that can be used to motivate people to work, namely (1) Need for achievement, (2) Need for affiliation, and (3) Need for power.

Self Management Practices is a person's ability to control and handle his own emotions in such a way that it has a positive impact on the implementation of tasks, has a sensitivity to the heart, and can delay pleasure before achieving a goal and able to recover from emotional stress (Rahmasari, 2018: 8). According to Castaneda et al., (2019) indicators of self-management practices are (1) Planning and Goal Setting, (2) Access Management, (3) Catch Up Activities, and (4) Emotional Management.

According to Sembiring (2020: 15), job satisfaction is the effect of quality work and the capacity achieved by an employee in carrying out his work following the burden that has been given. According to Estiningsih (2018: 50), job satisfaction is one of the most important elements in organizations. This is because job satisfaction can affect behaviors such as lazy, diligent, productive, etc., or have relationships with certain types of behaviors that are very important in the organization. According to Rivai (2018), some factors that affect job satisfaction are (1) Intrinsic Value, (2) Supervision, (3) Organization / Corporate Management, (4) Opportunity to Move Forward, (5) Salary and Benefits, (6) Co-Workers, and (7) Work Environment. 


\section{Frame of mind}

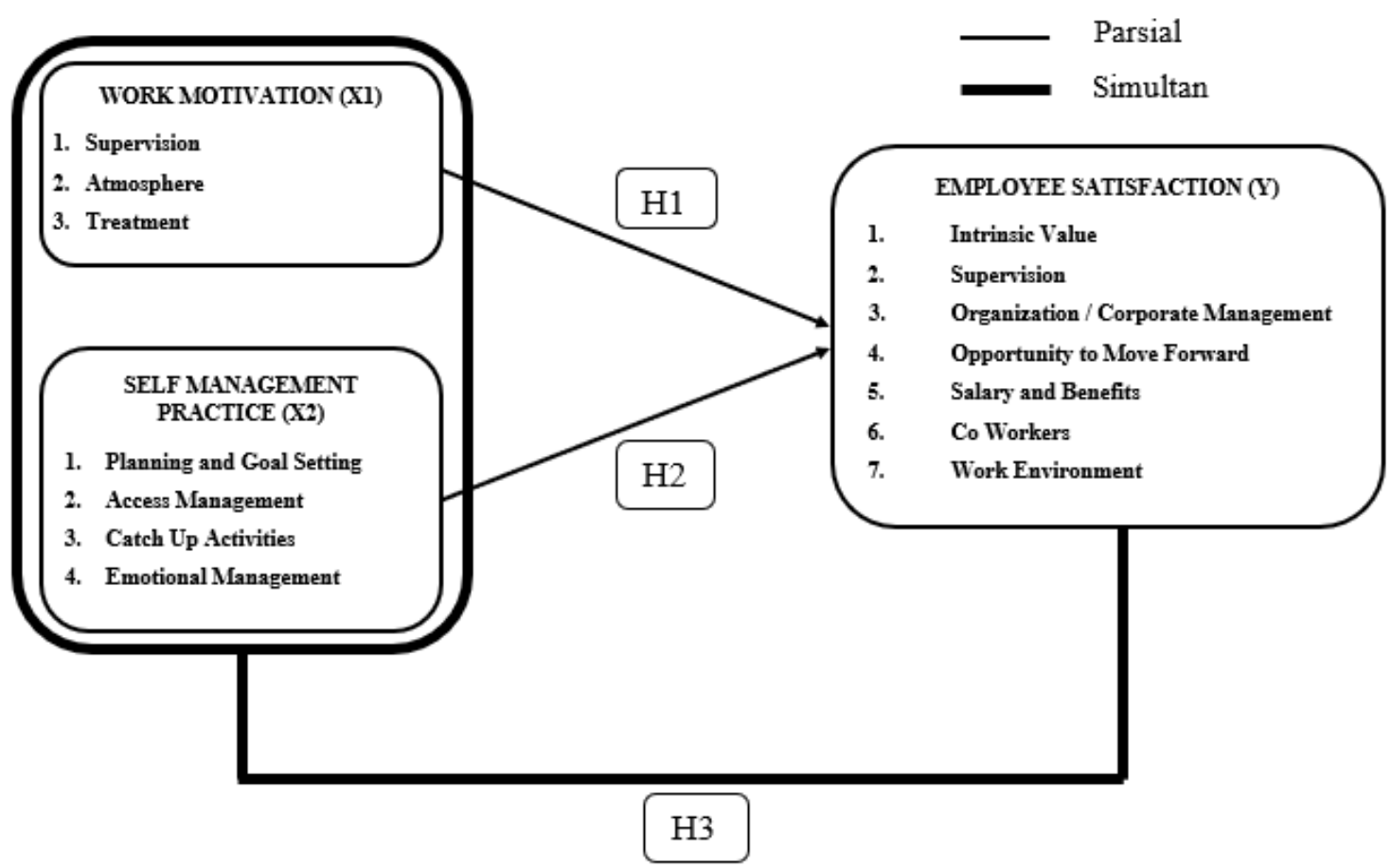

From the above frame of mind, it can be known, that the independent variables are Work Motivation (X1) and Self Management Practices (X2), while the dependent variable is Job Satisfaction (Y).

The hypotheses proposed in this study are as follows:

H1: There is a partial influence between work motivation (X1) on employee job satisfaction (Y).

$\mathrm{H} 2$ : There is a partial influence between self-management practices (X2) on employee job satisfaction (Y).

H3: There is an influence between work motivation (X1) and self-management practices (X2) simultaneously on employee job satisfaction (Y).

\section{Research methods}

\section{Types of Research}

The study will use a descriptive quantitative approach to explain the influence of work motivation variables and self-management practices on job satisfaction variables with multiple linear regression processes and processed using spss 25 for Windows applications. The sampling technique in this study, purposive sampling, is a type of sampling with attention to the considerations made by researchers. The size of the sample in this study was calculated using the Slovin formula so that the total sample calculation taken as many as 200 respondents were asked to fill out a research questionnaire. Each individual taken as a sample will be asked to fill out a questionnaire according to the Linkert scale with a scale of 1-5 (strongly disagree - strongly agree). Multiple line regression techniques are used to determine the magnitude of the influence of the Work Motivation variable (X1) and Self Management Practices (X2) on the Job Satisfaction variable $(\mathrm{Y})$. 


\section{Results and discussions \\ Multiple Regression Analysis}

Regression analysis is used to determine the existing relationships between variables so that the acquired relationship can be estimated for one variable if the price of another variable is known. The regression model equation used by the author is a double regression analysis equation. Below will be presented a regression equation model using several linear regression analyses, namely as follows:

Table 1. Multiple Linear Regression

\begin{tabular}{|c|c|c|c|c|c|c|}
\hline & \multirow{2}{*}{ Model } & \multicolumn{2}{|c|}{$\begin{array}{c}\text { Unstandardized } \\
\text { Coefficients }\end{array}$} & \multirow{2}{*}{$\begin{array}{l}\begin{array}{l}\text { Standardized } \\
\text { Coefficients }\end{array} \\
\text { Beta }\end{array}$} & \multirow{2}{*}{$\mathrm{t}$} & \multirow{2}{*}{ Sig. } \\
\hline & & B & Std. Error & & & \\
\hline \multirow[t]{3}{*}{1} & (Constant) & 10.386 & 2.406 & & 4.316 & .000 \\
\hline & $\mathrm{X} 1$ & .058 & .081 & .043 & .712 & .477 \\
\hline & $\mathrm{X} 2$ & .539 & .057 & .577 & 9.519 & .000 \\
\hline
\end{tabular}

As the result of the calculation, the constant value (a) is 10.386 and the value of Work Motivation (X1) is 0.058 and the value of Self Management Practices (X2) is 0.539. The regression equation formula is obtained as follows:

$$
Y=10,386+0,058 X_{1}+0,539 X_{2}+e
$$

1. If the constant value of 10.386 means that if the independent variable which is the variable of work motivation and self-management practices is considered constant (worth 0), then the dependent variable i.e. the job satisfaction variable will be worth 10,386 . That is, when there is no change in the value of work motivation and self-management practices, then the value of employee satisfaction does not change.

2. If the regression coefficient value of the work motivation variable shows 0.058 , meaning that if the work motivation variable increases by (one) unit, while the other independent variable that is the self-management practices variable is considered constant (worth 0), then the dependent variable that is the varying job satisfaction will increase by 0.058 . Positive signs on the regression value coefficient indicate that work motivation has a positive influence on employee job satisfaction. This means that the higher the work motivation, the higher the employee's job satisfaction, and vice versa.

3. If the regression coefficient value of the self-management practices variable shows 0.539 , meaning that if the self-management practices variable increases by (one) unit, while the other independent variable that is the work motivation variable is considered constant (worth 0 ), then the dependent variable that is varied job satisfaction will increase by 0.539 . Positive signs on the regression value coefficient indicate that self-management practices have a positive influence on employee job satisfaction. This means that the higher the value of selfmanagement practices, the higher the employee's job satisfaction, and vice versa. 
Table 2. Simultaneous Hypothesis Testing

\begin{tabular}{|ll|r|r|r|r|r|}
\hline & \multicolumn{1}{|c|}{$\begin{array}{c}\text { Sum of } \\
\text { Squares }\end{array}$} & df & \multicolumn{1}{c|}{$\begin{array}{c}\text { Mean } \\
\text { Square }\end{array}$} & F & Sig. \\
\hline \multirow{2}{*}{1} & $\begin{array}{l}\text { Regression } \\
\text { Residual } \\
\text { Total }\end{array}$ & 642.711 & 2 & 321.356 & 53.326 &, $000^{\mathrm{b}}$ \\
\cline { 2 - 5 } & 1187.164 & 197 & 6.026 & & \\
\hline
\end{tabular}

Conformity Test (F test) uses statistical test $F$ with research model $Y=\alpha+\beta 1 X 1+\beta 2 X 2$ + e. The F test result obtained the F count at 53,326 with a significance level of 0.000 . Since the significance value obtained is $0.000<0.05$, it can be concluded that this study has met the F test with its $\mathrm{F}$ value being 53,326 greater than $\mathrm{F}$ table 3,090.

Table 3. Determination Coefficient Test

\begin{tabular}{ll|r|r|r} 
& \multicolumn{3}{c}{ Model Summary $^{\mathbf{b}}$} \\
Model & $\mathrm{R}$ & R Square & \multicolumn{1}{c}{ Adjusted R Square } & \multicolumn{2}{c}{ Std. Error of the Estimate } \\
\hline 1 & $.593^{\mathrm{a}}$ & .351 & .345 & 2.45483 \\
\hline
\end{tabular}

a. Predictors: (Constant), TOTAL_X2, TOTAL_X1

b. Dependent Variable: TOTAL_Y

Based on the results of the Kuefisiensi Determination Test obtained a value of R Square of 0.351 , this means that there is an effect of $35.1 \%$ of work motivation variables (X1) and selfmanagement practices $(\mathrm{X} 2)$ variables on job satisfaction variables $(\mathrm{Y})$, and there is an effect of $35.1 \%$ by other variables not studied in this study.

\section{Descriptive Analysis}

\section{Discussion of Work Motivation at PT. Bio Farma}

The results showed that in the work motivation variable (X1) obtained the actual total score value of 5272, the ideal total score of 6000 percentage values of $88 \%$, falls into the category very well. This shows that the work motivation shown by employees of PT. Bio Farma is very good. Work motivation variables consist of (1) Need for achievement, (2) Need for affiliation, and (3) Need for power.

\section{Discussion of Self Management Practices at PT. Bio Farma}

The results showed that in the variable self-management practice (X2) obtained the actual total score value of 6981 , the ideal total score of 8000 percentage value of $87 \%$, falls into the category very well. This shows that self-management practice is indicated by employees of PT. Bio Farma is very good. Variable self-management practice consists of (1) Planning and Goal Setting, (2) Access Management, (3) Catch Up Activities, and (4) Emotional Management. 


\section{Discussion of Job Satisfaction at PT. Bio Farma}

The results showed that in the job satisfaction variable (Y) obtained the actual total score value of 6145 , the ideal total score of 7000 percentage values of $88 \%$, falls into the category very well. This shows that the job satisfaction shown by employees of PT. Bio Farma is very good. Job satisfaction variables consisting of (1) Intrinsic Value, (2) Supervision, (3) Organization/ Corporate Management, (4) Opportunity to Move Forward, (5) Salary and Benefits, (6) CoWorkers, and (7) Work Environment.

\section{Conclusion}

Based on the results of previous research and discussions, the following conclusions were obtained:

1. Referring to Test Results F shows that the Employee Job Satisfaction (Y) variable of PT. Bio Farma will be 53,326 points and this number has not been affected by variables (X1) Work Motivation and Self Management Practices (X2). However, the number was affected by other variables outside of the study.

2. From the results of the correlation coefficient (R) test obtained a value of 0.593 . So it can be concluded that the relationship of variable Work Motivation (X1) and Self Management Practices (X2) has a strong relationship with the Job Satisfaction variable (Y) which is $59.3 \%$.

3. From the results of the research the coefficient of determination (R2) obtained a value of 0.351 . This suggests that the contribution of variables to Work Motivation (X1) and Self Management Practices (X2) can affect Job Satisfaction (Y) by the remaining 35.1\% of the remaining $64.9 \%$ influenced by other variables not included in the study.

4. Work Motivation Variable (X1) has a regression coefficient of 0.058 and the selfmanagement practices (X2) variable has a regression value coefficient of 0.539 so it can be concluded if the company provides good Work Motivation (X1) and Self Management Practices (X2) then employee Job Satisfaction (Y) will increase.

\section{References}

[1] Afifah, T. \&. (2017). Pengaruh Kepuasan Kerja terhadap Motivasi Kerja dan Dampaknya terhadap Kinerja (Studi pada Karyawan PT Pertamina Geothermal Energy Kantor Pusat Jakarta). Jurnal Administrasi Bisnis, 122-129.

[2] Aldino, M. A. (2017). Pengaruh Kepemimpinan dan Disiplin terhadap Motivasi Kerja serta Dampaknya pada Kinerja Pegawai Rumah Sakit Umum Bersaudara Kabupaten Bungo. Jurnal Manajemen, 23-32.

[3] Andika, R. (2019). Pengaruh Motivasi Kerja dan Persaingan Kerja Terhadap Produktivitas Kerja Melalui Kepuasan Kerja sebagai Variabel Intervening Pada Pegawai Universitas Pembangunan Panca Budi Medan. Jumant, 189-206.

[4] Ghozali, I. (2016). Aplikasi Analisis Multivariate dengan Program IBM SPSS 23. Semarang: Badan Penerbit Universitas Diponegoro.

[5] Hamali, A. Y. (2016). Pemahaman Sumber Daya Manusia. Yogyakarta: CAPS.

[6] Harahap, R. (2018). Analisa kepuasan kerja karyawan di cv. rezeki medan. Jumant, 97102. 
[7] Hasibuan, M. S. (2016). Manajemen Sumber Daya Manusia. Jakarta: PT Bumi Aksara.

[8] Jufrizen, J. (2016). Efek Mediasi Kepuasan Kerja Pada Pengaruh Kompensasi Terhadap Kinerja Karyawan. Jurnal Ilmiah Manajemen Dan Bisnis, 17(1).

[9] Kasmir. (2016). Manajemen Sumber Daya Manusia (Teori dan Praktik). Jakarta: Raja Grafindo Persada.

[10] Kaswan. (2017). Psikologi Industru \& Organisasi. Bandung: Alfabeta.

[11] Khair, H. (2019). Pengaruh Kepemimpinan dan kompensasi terhadap kepuasan kerja melalui motivasi kerja. Jurnal Ilmiah Magister Manajemen, 69-88.

[12] Mujiatun, S. J. (2019). Model Kelelahan Emosional: Antaseden Dan Dampaknya Terhadap Kepuasan Kerja Dan Komitmen Organisasi Dosen. MIX: Jurnal Ilmiah Manajemen, 447-465.

[13] Noor, J. (2015). Analisis Data penelitian Ekonomi Dan Manajemen. Jakarta: Grasindo.

[14] Priansa, D. J. (2014). Perencanaan dan Pengembangan SDM. Bandung: Alfabeta.

[15] Rolos, J. K. (2018). Pengaruh Beban Kerja Terhadap Kinerja Karyawan Pada PT. Asuransi Jiwasraya Cabang Manado Kota. Jurnal Administrasi Bisnis, 19-27.

[16] Siagian, T. S. (2018). Pengaruh Gaya Kepemimpinan Dan Lingkungan Kerja Terhadap Kinerja Karyawan Dengan Kepuasan Kerja Sebagai Variabel Intervening. Maneggio: Jurnal Ilmiah Magister Manajemen, 59-70.

[17] Soeriawibawa, R. D. (2017). Pengaruh Kompensasi Terhadap Motivasi Kerja Karyawan Bagian Produksi CV.Triady Motor. SMART Study \& Management Research, 10-17.

[18] Sukarja, R. \&. (2016). Pengaruh Kepemimpinan dan Komunikasi terhadap Kepuasan Kerja dan Kinerja Pegawai Dinas Pendidikan Provinsi Riau. Jurnal Tepak Manajemen Bisnis, 270-284.

[19] Sutrisno, E. (2016). Manajemen Sumber Daya Manusia. Jakarta: Kencana.

[20] Suwatno, \&. P. (2018). Manajemen SDM dalam Organisasi Publik dan Bisnis. Bandung: Alfabeta.

[21] Yakub, Y. (2017). Pengaruh Keterlibatan Kerja, Budaya Organisasi dan Motivasi Kerja terhadap Kepuasan Kerja Pegawai. Islamic Banking and Finance Journal, 273-290.

[22] Yusnandar, W. (2019). Effect of Work Environment and Job Satisfaction on The Performance of Employees at The Office of Bank Indonesia Medan North Sumatera. In International Conference on Global Education VII, 1575-1583. 